\title{
MODERN CHRISTOLOGICAL TRENDS
}

\section{Reflections on a recent notable book}

The book* provides a discerning and detailed survey of the relation and

* "The Incarnation: Trends in Modern Anglican Thought," by Lewis B. Smedes. Kampen. J. H. Kok, 1953.

accommodation of theological ideas and Christological doctrines to the various scientific, psychological and philosophical schools of thought of the last sixty years. The writers most quoted are rightly described as "liberal Catholic" and "modern Anglo-Catholic," and include C. Gore, R. C. Moberly, Wm. Temple, O. C. Quick, L. S. Thornton, E. L. Mascall, A. G. Hebert and A. M. Ramsay. Dr. Smedes' able survey is most revealing in its indication of the various governing ideas which inform and inspire AngloCatholic faith and worship, and determine Anglo-Catholic views of the Cross, the Church, the Sacraments and the way of salvation, or rather of human integration and fulfilment.

Let us make some brief selections from Dr. Smedes' findings. Three current movements of thought conditioned the approach of the contributors to "Lux Mundi" (1889) (i) natural evolution, (ii) philospophical idealism, (iii) higher criticism of the Bible. These writers thought they could have it both ways, and welcome such current ideas without abandoning Christian faith. By resort to a "Kenosis" theory Gore was able to argue that errors in matters of fact need not in the least impugn Christ's moral perfection. This "had the appearance of a theological emergency measure."

In the thought of Wm. Temple and O. C. Quick such "Kenosis" ideas were superseded by ideas of divine fulfilment. The essence of God is selfrealization through self-sacrifice. God did not empty Himself in the Incarnation-He took a big jump towards realizing Himself. More recently, in the thought of E. L. Mascall and L. S. Thornton, such ideas have been complemented by ideas of human elevation and fulfilment through the Incarnation. In Christ, through its union with God, human nature is supernaturalized or taken up into a higher metaphysical perfection. What is needed to complete humanity is perfect filial response. This exists to begin with only in the divine Son and is achieved by the organic creation only when it is taken up into His activity. This means consummation through the Incarnation rather than salvation through atonement. So there has been (to quote Wm. Temple) " the development of a theology of the Incarnation rather than a theology of Redemption."

Men may now share in the achievement of the Incarnation through incorporation into Christ's human nature. This means a genuine metaphysical re-creation, an ontological change, in contrast to the Protestant idea of atonement as a "legal fiction," which leaves man essentially what he was. The Church provides the sphere of participation. It is the extension of the divine human organism started in Christ. Men are saved by incorporation into this organism of Incarnation. This means that the Church is the "place" where reconciliation with God occurs, the "sphere" into which individuals enter in order to share in the divine life. Protestants are prevented from thus believing in a real ontological coherence of the Church and the humanity of Christ by their doctrine of justification.

The Cross does not procure the new life. It is rather, on the one hand. "a necessary passage through which the Incarnation must go to reach us," and, on the other hand, the crowning expression of the governing principle of the Incarnation, namely, obedient self-sacrifice. The Church, by being baptized into its spirit, and into participation in its self-sacrificing offering, gives the Incarnation not only extension but also true and necessary completion.

Christ's humanity is thus manifested under different forms or modes,through His earthly body, His glorified body, His body the Church and the eucharistic body. "They are all," says E. L. Mascall, "objective forms of expression of the manhood of the one Lord." (The present writer has tried to help his mind to grasp this strange idea by rather distant analogy that steam, water and ice are different modes of the same distinctive combination of hvdrogen and oxygen.) Christ thus offers Himself now in the humanity we share with Him. The eucharist is its externalisation in ritual form. The 
Church form of the Incarnation thus finds in the eucharist the supreme occasion of the expression of its governing life-principle of self-sacrifice. In the eucharist "offerers and offered are one, since both are modes of the body of Christ. When believers perform the eucharistic rite, they offer themselves in offering the elements. Further, Christ offers Himself as the believers offer the eucharistic sacrifice, since it is His humanity which the believers offer in offering themselves and the sacrifice." The eucharist is thus a making present in time of what is true in eternity.

In conclusion, Dr. Smedes offers a criticism of these ideas in the light of the Biblical witness. First, the Biblical doctrine of creation leaves us with an unavoidable impression that man, created in the image of God, was a completed being. So man did not need an Incarnation of God in order to fulfil his vocation of total worship. This cancels out the prevailing premiss of these writers as to the purpose of the Incarnation-that it was required by the nature of creation, and would have occurred even had not sin entered man's life. Second, according to the Bible, man's relation to God has been disrupted by the fall. So man's need of the Incarnation was religious, not metaphysical - a need of reconciliation not elevation, of meditation not metaphysical completion. This confirms the alternative premiss of Dr. Smedes that the Incarnation was solely the divine remedy for the evil brought into the world by man's fall into sin. The Biblical presentation of the Christ fits perfectly the Biblical presentation of the need.

Dr. Smedes consequently contends that such "modern Anglican Christology" as he has surveyed "has in common an unbiblical thesis as to the purpose of the Incarnation." It is dominated by the "tendency to rationalize the Incarnation by taking it out of its Biblical setting of creation, sin and redemption and putting it within a semi-speculatve setting of man's metaphysical incompletion."

Since such Anglo-Catholic thought and teaching are widely prevalent and have their own obvious attraction for the religiously and philosophically minded, it is of urgent practical importance that their fundamental errors should be both properly appreciated and properly answered. Dr. Smedes' thesis does both. Although written by an American, and published in Holland, it therefore merits particular attention in this country, not least by evangelical Anglicans, or by any engaged in work for God among young converts who are exposed to the obvious natural fascination of AngloCatholic thought and practice.

Oak Hill College,

London, N.14.

A. M. STIBbS.

\section{UNPUBLISHED HYMNS BY CHARLES WESLEY}

Among the autograph manuscripts of hymns by Charles Wesley which are in the custody of the Epworth Press, City Road, are five volumes of short hymns on the Gospels and the Book of Acts. They vary in length from 195 pages (Mark) to 555 pages (Acts).

In search of variant readings, I began to collate the hymns in manuscript with Volume ii of Short Hymns on Select Passages of Holy Scripture, first published in 1762, and with the supposedly definitive Poetical Works of 1868-72. To my surprise, I began to find hymns in manuscript which were not included in either publication. Among the hymns on the Gospel of Mark alone, there are 46 unpublished hymns or portions of hymns.

The Short Hymns are in the nature of brief devotional verse expositions; the following is typical, and one cannot help wondering why it was ever omitted; the text chosen for exposition is Mark xv, 39.

"How powerful our Redeemer's cries Which life in death impart,

Which open still the sinner's eyes, And pierce his echoing heart!

By faith I hear his speaking blood, His mangled form I see,

And know, This is the Son of God, Whose cries converted me."

Tyndale House,

Cambridge.

J. Dale.

The Ridley Press, Cambridge and St. Ives. 